\title{
URS F FLETE - THE FIRST OAT CULTIVAR FOR FORAGE PRODUCTION IN SOUTHERN BRAZIL
}

\author{
Luiz Carlos Federizzi ${ }^{1}$, (D) Miguel Dall'Agnol ${ }^{1}$, (D) Marcelo Teixeira Pacheco ${ }^{1}$ \\ and (iD) Roberto Luis Weiler ${ }^{1 *}$ \\ 1 Universidade Federal do Rio Grande do Sul, Faculdade de Agronomia, Av. Bento Gonçalves 7712, \\ CEP 90001-970, Porto Alegre, RS, Brazil. \\ *Corresponding author: Roberto LuisWeiler(robertoluisw@yahoo.com.br)
}

\begin{abstract}
The oat cultivar "URS F Flete" (Avena sativa) registration number 32980 from the Brazilian Ministry of Agriculture, Livestock and Food Supply (MAPA), was developed from the cross 'LA 9339E17 $x$ LAO-591-NZ 0553' and is the first cultivar bred for the environmental conditions which predominate in southern Brazil. The cultivar hashigh forage production and good resistance to the main diseases that occur in the region.
\end{abstract}

Keywords: Avena sativa, forage yield, oat breeding program.

\section{Introduction}

There are several species within the genus Avena, but in Brazil only $A$. sativa (white oat) and A. strigosa (black oat) are usually grown. Black oat is traditionally used as a forage crop while white oatproduces grainfor the food industry. UFRGS has a strong breeding programand has released $>30$ cultivars, which account for the majority of white oats grownin Brazil. However, due to foliar and stem fungal diseases, more white oats are sown for animal forage, due the release of dual-purpose cultivars. These cultivars can be grazed or conserved as hay or silage.

Avena sativa is an allohexaploid plant with genomes"A", "C" and "D" from ancestral diploid species (Latta et al., 2019). The hexaploid genome is challenging to sequence and the oat genome sequencing project initially focused on diploid species. Species within Avena can hybridize and genes introduced from other "A" genome species. This has contributed many valuable traits, such as crown rust (Puccinia coronata) resistance (Maughan et al., 2019).

In Rio Grande do Sul, white oat is recommended for establishment from March to May for pasture, and from May to July, for grain production. It can be sown in mixtures with species including ryegrass, vetch, white clover, red clover, arrowleaf clover and subterranean clover (Fontaneli and Freire Junior, 1991) to create winter active pastures. The objective of this work is to present the pedigree, breeding method, and agronomic performance of the new released oat cultivar "URS F Flete".

\section{Pedigree and breeding method}

The cultivar "URS F Flete" was obtained from the crossing carried out at the Experimental Station of the University of Florida of Quincy under the Quaker Oats International Nursery 
Program (QOIN) in 1999. The immediate parents are LA 9339E17 x LAO-591-NZ 0553 and the genealogy of the two parental lines are LA 9339E17 $=$ X414 / T91AB3256 and LAO-591NZ0553 = ACMedallion $/$ OT257. It was introduced in Brazil in May 2000 in the $F_{3}$ generation. Due to the procedures and quarantine requirements sowing was delayed until June 2001 at the UFRGS Experimental Agronomic Station. The selections were carried out from 2001 to 2009 , using a pedigree modified breeding method described previously by Nava et al. (2016).

In 2001, the $F_{2}$ generation was sown in two rows $2.0 \mathrm{~m}$ long with the number Q00/242. In these rows, plants were selected based of the cycle, height and health, with five panicles being harvested. In the laboratory, the grains were evaluated and two panicles were discarded, with the remaining three panicles giving rise in 2002 to two double lines of $2.0 \mathrm{~m}$ long. From "line 1" four panicles were selected, which were sown in double lines of $2.0 \mathrm{~m}$ length in 2003, These gave rise to four double lines of $2.0 \mathrm{~m}$ length in the field in 2004 called 04Q26-1 to 4. In 2004, 10 panicles were selected in the field based on plant height, cycle and resistance to diseases from line 04Q26-2.

At each subsequent segregating generation, only whole panicles were selected in the field, and later threshed individually. The grains were screened in the laboratory for size, grain filling, uniformity and absence of diseases, such as black spots (Phaeosphaeria avenariaf.sp. avenaria) and fusarium (Fusarium graminearum) (Pacheco and Federizzi, 2020).
In the laboratory, four panicles were discarded and the remaining six were selected based on the quality of the grains. These were sown in 2005 under numbers 05Q03-1 to 6. In 2005,16 panicles were selected at the field from line 05Q03-4, based on plant height, cycle and disease resistance. After selection, 10 panicles remained, which in 2006 gave rise to the 06Q8004 family, with 10 strains, named 06Q8004-1 to 06Q8004-10. In the line 06Q80046 , six panicles were selected and afterlaboratory analysis three panicles remained.

These panicles were sown in 2007 and were named 07Q9017-1 to 3. In line 07Q9017-2, five panicles were selected in the field based on cycle and disease resistance. After selection in the laboratory for grain quality, four panicles remained. These panicles were sown in double lines $2.0 \mathrm{~m}$ long and were called 08Q10011-1 to 4. In line 08Q10011-1, six panicles were selected. After laboratory testing, three panicles remained. These were sown in the field in 2009 and were called 09Q11004-1 to 3. These strains were phenotypically uniform and the line 09Q11004-1 was harvested in bulk giving rise to line 0911004-1.

From 2011 to 2013, line 09 11004-1 was tested for forage yield in three locations in Rio Grande do Sul/Brazil (Table 1), Coronel

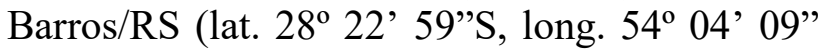
$\mathrm{W}$, alt. $311 \mathrm{~m}$ a.s.1.), Bagé/RS (lat. $31^{\circ} 21^{\prime} 09^{\prime}$ S, long. $54^{\circ} 00^{\prime} 57^{\prime \prime} \mathrm{W}$, alt. $230 \mathrm{~m}$ a.s.1.) and Eldorado do Sul/RS (lat. $30^{\circ} 05^{\prime} 26^{\prime \prime} \mathrm{S}$, long. $51^{\circ}$ 40 ' 42 " W, alt. $41 \mathrm{~m}$ a.s.1.).

Table 1. Characterization of the evaluation sites of the cultivar "URS F Flete".

\begin{tabular}{|c|c|c|c|c|}
\hline City/State* & Altitude & Latitude & Sowing & Soil Type \\
\hline Coronel Barros/RS & 311 & 28ㅇ2'59" & April 2011 & \multirow{2}{*}{ Haplortox } \\
\hline Coronel Barros/RS & 311 & $28 \div 22^{\prime} 59^{\prime \prime}$ & April 2012 & \\
\hline Bagé/RS & 230 & 31은' $52 "$ & May 2011 & \multirow{2}{*}{ Alfisol } \\
\hline Bagé/RS & 230 & 31은' $52^{\prime \prime}$ & May 2012 & \\
\hline Eldorado do Sul/RS & 40 & $30 \div 06^{\prime} 22^{\prime \prime}$ & May 2011 & \multirow{2}{*}{ Ultisol } \\
\hline Eldorado do Sul/RS & 40 & $30 \div 06 ' 22^{\prime \prime}$ & May 2012 & \\
\hline
\end{tabular}

*Rio Grande do Sul (RS), Brazil.

\section{Performance}

"URS F Flete" is the first white oat cultivar for forage production, developed for the conditions of southern Brazil that. In addition to high forage yields, it also has good resistance to the main foliar diseases that occur in the region, early forage production and also a reasonable seed yield. The oat cultivar "URS F Flete" is recommended for the three southern states of Brazil, climate classified as $\mathrm{Cfb}$ and $\mathrm{Cfa}$ (Köeppen, 1948). Accumulated fresh matter yield (kg FW 
$\mathrm{t} / \mathrm{ha})$ and dry matter production $(\mathrm{kg} \mathrm{DM} / \mathrm{ha})$ of cultivar "URS F Flete" in three locations and for two years compared to two commercial cultivars is presented in Tables 2 and 3.

Table 2. Accumulated fresh matter yield (kg FW t/ha) of cultivar "URS F Flete" in three locations and for two years compared to two commercial cultivars.

\begin{tabular}{lcccc}
\hline Location & Year & URS F Flete & FAPA 43 & IGUAÇÚ \\
\hline Coronel Barros/RS & 2011 & 85505 & 80514 & 80615 \\
\hline Coronel Barros/RS & 2012 & 38100 & 37256 & 31955 \\
\hline Bagé/RS & 2011 & 35566 & 36133 & 32733 \\
\hline Bagé/RS & 2012 & 39674 & 36652 & 37744 \\
\hline Eldorado do Sul/RS & 2011 & 49635 & 46124 & 46732 \\
\hline Eldorado do Sul/RS & 2012 & 42751 & 29312 & 39312 \\
\hline Mean & & $\mathbf{4 8 5 3 9}$ & $\mathbf{4 4 3 3 2}$ & $\mathbf{4 4 8 4 9}$ \\
\hline
\end{tabular}

Table 3. Dry matter production (kg DM/ha) from cultivar "URS F Flete" in three locations and for two years compared to two commercial cultivars.

\begin{tabular}{lcccc}
\hline Local & Year & URS F Flete & FAPA 43 & IGUAÇÚ \\
\hline Coronel Barros/RS & 2011 & 10434 & 10323 & 10290 \\
\hline Coronel Barros/RS & 2012 & 6345 & 5790 & 5326 \\
\hline Bagé/RS & 2011 & 5050 & 5021 & 4953 \\
\hline Bagé/RS & 2012 & 5088 & 4410 & 5045 \\
\hline Eldorado do Sul/RS & 2011 & 6469 & 5950 & 5461 \\
\hline Eldorado do Sul/RS & 2012 & 5909 & 4973 & 5764 \\
\hline Mean & & $\mathbf{6 5 4 9}$ & $\mathbf{6 0 7 8}$ & $\mathbf{6 1 4 0}$ \\
\hline
\end{tabular}

\section{Seed production}

"URS F Flete" is recognized by the Brazilian Ministry of Agriculture, Livestock and Food Supply (MAPA) under registration number $32980(09 / 12 / 2016)$ and the protection number $0170172(01 / 23 / 2017)$. Genetic seeds stock is maintained by Universidade Federal do Rio Grande do Sul, Faculdade de Agronomia, Av. Bento Gonçalves 7712, CEP 90001-970, Porto Alegre, RS, Brazil. Certified seed are produced by the South-Brazilian Association for the Pro- motion of Forage Research - SULPASTO and is available for sowing on commercial properties in the season 2020.

\section{Acknowledgments}

We thank the CAPES (Brazilian Federal Agency for Support and Evaluation of Graduate Education), CNPq (Brazilian Council for Scientific and Technological Development) and the South-Brazilian Association for the Promotion of Forage Research (SULPASTO) for financial support and grants.

\section{References}

FONTANELI, R.S.; FREIRE JUNIOR, N. 1991. Avaliação de consorciações de aveia e de azevém anual com leguminosas de estação fria. Pesquisa Agropecuária Brasileira, 26(5): 623-630.

KÖEPPEN, W.1948. Climatologia: com un estudio de los climas de la tierra. Mexico, Fondo de Cultura Economica, 478p.

LATTA, R.G.; BEKELE, W.A.; WIGHT, C.P.; TINKER, N.A. 2019. Comparative linkage mapping of diploid, tetraploid, and hexaploidy Avena species suggests extensive chromosome rearrangement in ancestral diploids. Scientific Reports, 9:12298. 
MAUGHAN, P.J.; LEE R., WALSTEAD, R.; VICKERSTAFF, R.J.; FOGARTY, M.C.; BROUWER, C.R.; REID, R.R.; JAY, J.J.; BEKELE, W.A.; JACKSON, E.W.; TINKER, N.A.; LANGDON, T.; SCHLUETER, J.A.; JELLEN, E.N. 2019. Genomic insights from the first chromosome-scale assemblies of oat (Avena spp.) diploid species. BMC Biology, 17(92):1-19.

NAVA, I.C.; PACHECO, M.T.; FEDERIZZI, L.C. 2016.URS Altiva - a new oat cultivar with high agronomic performance. Crop Breeding and Applied Biotechnology, 16(3):254-260.

PACHECO, M.T.; FEDERIZZI, L.C. 2020. URS MONARCA - a new hexaploid oat cultivar with excellent grain yield and wide adaptation. Crop Breeding and Applied Biotechnology, 20 (2): e306220213. 